\title{
Pengaruh Persepsi atas Media Pembelajaran dan Minat Baca terhadap Kemampuan Menulis Teks Editorial
}

\author{
Imas Kusmiati ${ }^{1)}$ \\ Universitas Indraprasta PGRI \\ Jalan Nangka No. 58 C/TB. Simatupang, Tanjung Barat, Jakarta Selatan 12530 \\ Nurdin ${ }^{2)}$ \\ Universitas Indraprasta PGRI \\ Jalan Nangka No. 58 C/TB. Simatupang, Tanjung Barat, Jakarta Selatan 12530 \\ Masrin $^{3)}$ \\ Universitas Indraprasta PGRI \\ Jalan Nangka No. 58 C/TB. Simatupang, Tanjung Barat, Jakarta Selatan 12530 \\ kusmiati.imas@gmail.com ${ }^{1)}$
}

\begin{abstract}
The purpose of this study was to analyze the effect of perception on learning media and reading interest on the ability to write editorial texts. The research method used was a survey research method with multiple regression analysis. The research sample was 75 people. The results of this study illustrate: (1) There is a significant influence of perceptions on learning media and reading interest in the ability to write editorial texts for state high school students in Sukabumi District. (2) There is a significant influence of perceptions on instructional media on the ability to write editorial texts of students, (3) There is a significant influence of reading interest on the ability to write editorial texts.
\end{abstract}

Keywords: Learning Media, Interest in Reading, Editorial Texts

\begin{abstract}
Abstrak
Tujuan Penelitian ini adalah untuk menganalisis pengaruh persepsi atas media pembelajaran dan minat baca terhadap kemampuan menulis teks editorial. Metode penelitian yang digunakan adalah metode penelitian survey dengan analisis regresi ganda. Sampel penelitian berjumlah 75 orang. Hasil penelitian ini menggambarkan: (1) Terdapat pengaruh yang signifikan persepsi atas media pembelajaran dan minat baca terhadap kemampuan menulis teks editorial siswa SMA Negeri di Kabupaten Sukabumi. (2) Terdapat pengaruh yang signifikan persepsi atas media pembelajaran terhadap kemampuan menulis teks editorial siswa. (3) Terdapat pengaruh yang signifikan minat baca terhadap kemampuan menulis teks editorial.
\end{abstract}

Kata Kunci: Media Pembelajaran, Minat Baca, Teks Editorial

\section{PENDAHULUAN}

Kemampuan berbahasa merupakan hal yang penting dalam berkomunikasi. Terdapat empat kemampuan berbahasa yang saling mempengaruhi satu sama lain. Keempat kemampuan tersebut yaitu kemampuan menyimak, kemampuan berbicara, kemampuan membaca, dan kemampuan menulis. Keterampilan menulis teks editorial adalah keterampilan yang paling 
asing bagi siswa. Sebagian besar mereka tidak tentang apa dan bagaimana bentuk serta isi teks editorial. Hal tersebut terjadi karena mereka sangat jarang membaca surat kabar.

Empat keterampilan berbahasa seseorang pada umumnya didapatkan melalui proses yang beraturan dan berurutan. Pertama, sejak lahir seseorang akan belajar menyimak kemudian disusul dengan kemampuan berbicara. Seseorang dapat berbicara tentu saja dipengaruhi oleh kemampuan menyimak sebelumnya. Dia berbiacara dengan kosa kata yang disimaknya kemudian ditiru dan diucapkan sebagai ucapannya sendiri. Keterampilan menyimak dan berbicara terjadi melalui proses alamiah dan langsung dalam porses komunikasi yang didukung oleh alat ucap yang baik.

Keterampilan membaca dan menulis diperoleh secara sengaja melalui proses belajar. Keduanya digunakan dalam komunikasi tertulis dan secara tidak langsung. Menyimak/ mendengarkan, berbicara, membaca, serta menulis merupakan keterampilan yang melalui proses perkembangan.

Menulis merupakan sebuah keterampilan produktif dalam berbahasa yang memerlukan pengalaman, waktu, latihan, keterampilan khusus, dan pengajaran langsung. Keterampilan ini bersifat produktif dan ekspresif, yang tidak akan diperoleh secara otomatis melainkan melalui latihan, praktik, dan pembimbingan.

Tujuan akhir dari proses pembelajaran bahasa di sekolah adalah siswa memiliki empat kemampuan berbahasa seperti yang sudah dipaparkan di atas. Menulis menjadi salah satu keterampilan berbahasa yang sudah semestinya dimiliki oleh siswa. Tujuan pengajaran menulis yang dilakukan di sekolahsekolah ada empat. Keempat tujuan tersebut yaitu membantu para siswa memahami bagaimana caranya ekspresi tulis dapat melayani mereka, dengan jalan menciptakan situasi-situasi di dalam kelas yang jelas memerlukan karya tulis dan kegiatan menulis, mendorong para siswa mengekspresikan diri mereka secara bebas dalam tulisan, mengajar para siswa menggunakan bentuk yang tepat dan serasi dalam ekspresi tulis, mengembangkan pertumbuhan bertahap dalam menulis dengan cara membantu para siswa menulis sejumlah maksud dengan sejumlah cara dengan penuh keyakinan pada diri sendiri secara bebas.

Keempat tujuan di atas akan tercapai apabila siswa memiliki kemauan dan kemampuan. Sayangnya, kenyataan di lapangan menunjukkan sebaliknya. Pembelajaran menulis di sekolah-sekolah merupakan kegiatan yang kurang diminati. Penulis sudah sering sekali menemukan kasus yang mengindikasikan bahwa siswa tidak mampu atau tidak tertarik dengan pembelajaran menulis. Bagi mereka, pembelajaran menulis cukup memberatkan. Banyak faktor yang menjadi penyebab orang kurang menyukai menulis. Menurutnya, seseorang tidak tertarik menulis karena tidak paham untuk apa dia menulis, merasa tidak memiliki bakat dalam menulis, tidak memahami bagaimana harus menulis. Graves juga mengemukakan apa saja manfaat dari menulis yaitu menulis menyumbang kecerdasan, menulis dapat mengembangkan daya imajinasi, menulis menumbuhkan keberanian, dan menulis mendorong kemauan dan kemampuan mengumpulkan informasi.

Keterampilan menulis teks editorial adalah keterampilan yang paling asing bagi siswa. Sebagian besar tidak mengenal apa dan bagaimana bentuk serta isi 
teks editorial. Hal tersebut terjadi karena mereka sangat jarang membaca surat kabar. Padahal, pengalaman membaca akan mempengaruhi kemampuan menulis dan berpikir mereka. Dalam sebaran KI/KD kurikulum 2013 kelas XII SMA/SMK terdapat kompetensi dasar merangkai teks editorial. Merangkai yang dimaksud adalah menulis atau menciptakan. Hal tersebut tentu akan sangat berat jika bentuk teks editorial ini saja siswa banyak yang belum tahu. Teks editorial ini memang berbeda dengan teks lainnya. Teks ini memiliki ciri khas yaitu opini penulis. Jika siswa jarang membaca tentu perbendahaaran kata mereka terbatas dan mereka akan kesulitan menulis apalagi tulisan berupa opini. Dalam hal ini, minat baca siswa sangat berpengaruh terhadap kemampuan menulis.

Evaluasi pembelajaran menulis di sekolah tempat penulis mengajar yaitu SMA Negeri I Parung Kuda hampir selalu menghasilkan nilai yang rendah. Tidak banyak siswa yang mampu menghasilkan tulisan yang baik. Suatu ketika penulis melakukan observasi di kelas pada saat pembelajaran menulis. Pada saat itu, kelas terlihat gaduh. Siswa saling bertanya satu sama lain tentang apa yang akan mereka tulis. Hampir dua puluh menit jam pelajaran berlangsung, masih ada yang belum menulis sama sekali. Berangkat dari sana, penulis kemudian melakukan wawancara tidak terstruktur dengan beberapa siswa. Beragam pendapat penulis dapatkan dari wawancara tersebut. Siswa tidak mampu menulis karena tidak berminat. Ada juga yang mengatakan bahwa menulis itu terlalu berat apalagi bentuknya teks editorial yang harus mengemukakan pendapat. Siswa lain mengatakan tidak bisa menulis teks editorial karena jarang Pembaca jadi tidak punya banyak pengetahuan. Alasan lain yang terlontar adalah kesulitan menemukan ide, tidak menyukai tema yang ditentukan, sudah punya ide, tetapi sulit menuangkan dalam kata-kata.

Pada dasarnya, siswa yang tidak menulis karena jarang membaca, perlu digali dan dirangsang minatnya untuk membaca. Siswa yang kesulitan menulis karena tidak menyukai temanya harus dipilihkan tema yang disukainya. Siswa yang kesulitan menuangkan ide sebenarnya mereka kekurangan informasi tentang apa yang akan ditulisnya. Siswa tersebut memerlukan bahan bacaan yang bisa membantu mengembangkan idenya.

Kasus-kasus di atas menunjukkan rendahnya minat menulis dan betapa beratnya pembelajaran menulis bagi siswa Selain kurangnya minat baca, rendahnya kemampuan menulis siswa juga dipengaruhi oleh kurang maksimalnya peranan guru dalam menggunakan metode, teknik, media, atau bahan ajar. Guru harus kreatif dalam memilih media pembelajaran.

Media pembelajaran sangatlah beragam. Diperlukan kejelian dalam memilih media pembelajaran agar sesuai dengan materi yang hendak diajarkan. Berkaitan dengan pembelajaran menulis opini dalam hal ini editorial, perlu digunakan media pembelajaran yang memiliki kemiripan karakteristik. Persepsi adalah pandangan terhadap suatu hal yang menyangkut sikap dan perilaku. Persepsi dapat mempengaruhi sikap dan perilaku. Siswa bisa saja memiliki persepsi positif dan negatif terhadap suatu proses pembelajaran termasuk media pembelajaran yang digunakan. Misalnya ada siswa yang antusius terhadap media yang digunakan, ada yang biasa-biasa saja dan tidak terpengaruh. Persepsi terhadap media pembelajaran berpengaruh terhadap sikap dan perilaku siswa 
dalam memgikuti pembelajaran yang pada akhirnya akan berpengaruh pula pada hasil pembelajarannya.

Membaca adalah salah satu aktivitas yang dapat meningkatkan wawasan dan pengetahuan. Selain itu, membaca juga dapat menambah perbendaharaan kata, mengasah berpikir kritis dan berargumentasi. Siswa yang memiliki minat baca tinggi akan selalu tertarik dengan berbagai bahan bacaan termasuk bacaan yang berupa berita-berita teraktual. Semakin banyak membaca, pengetahuan, wawasan, dan kemampuan berpikir seseorang akan meningkat. Selama ini, siswa kurang mampu menulis karena kurangnya wawasan mengenai suatu topik dan ketidakmampuan berargumentasi.

Berdasarkan pemaparan di atas, maka rumusan masalah dalam penelitian ini adalah bagaimana pengaruh persepsi atas media pembelajaran dan minat baca terhadap kemampuan menulis teks editorial?

\section{METODE}

Metode yang penulis gunakan dalam penelitian ini adalah metode survei. Adapun teknik analisis yang penulis gunakan adalah analisis regresi Linier Berganda. Penelitian ini dilaksanakan di SMA Negeri di Kabupaten Sukabumi, pada bulan September sampai dengan bulan Desember 2017. Jumlah sampel dalam penelitian ini sebanyak 75 siswa. Hubungan antara ketiga variabel tersebut dapat digambarkan sebagai berikut.

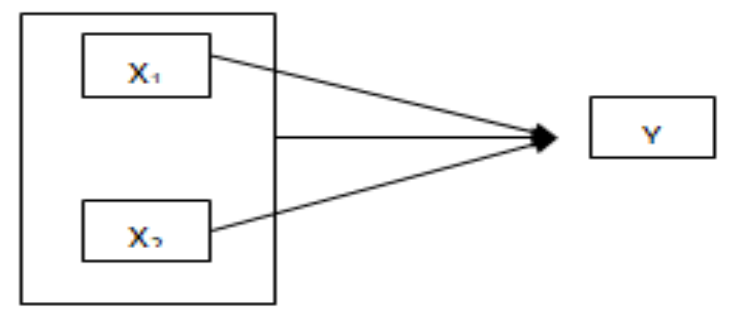

\section{Gambar 1. Konstelasi Hubungan Antar Variabel}

Keterangan

$\mathrm{X}_{\mathrm{I}}=$ Persepsi Atas Media Pembelajaran

$\mathrm{X}_{2}=$ Minat Baca

$\mathrm{Y}=$ Kemampuan Menulis Teks Editorial

Sebagaimana dijelaskan di atas, bahwa ada tiga jenis data yang dikumpulkan dalam penelitian ini. Ketiga sumber data tersebut didasarkan pada tiga variabel penelitian, yakni data tentang variabel bebas $\left(\mathrm{X}_{1}\right)$ yaitu Persepsi atas media pembelajaran, variabel bebas $\left(\mathrm{X}_{2}\right)$ yaitu minat baca, dan variabel terikat $(\mathrm{Y})$ yaitu kemampuan menulis teks editorial yang dikumpulkan dengan menggunakan kuesioner.

Sebelum kuesioner, terlebih dahulu diadakan analisis instrumen, melalui uji coba instrumen yang terdiri dari uji validitas, uji reliabilitas, daya pembeda 
serta tingkat kesukaran, dimaksudkan mengetahui kelayakan instrumen untuk dijadikan sebagai instrumen penelitian.

\section{HASIL DAN PEMBAHASAN}

\section{Landasan Teori}

\section{Kemampuan Menulis Teks Editorial}

Kemampuan merupakan potensi yang dimiliki seseorang untuk melakukan sesuatu. Dalam kegiatan apapun diperlukan kemampuan untuk melaksanakannya agar tercapai tujuan yang diinginkan. Menurut Kamus Besar Bahasa Indonesia (KBBI), mampu artinya sanggup melakukan sesuatu., sedangkan kemampuan adalah kesanggupan, kecakapan, kekuatan.

Rusyana (1984: 191) mengatakan bahwa menulis merupakan kemampuan menggunakan pola-pola bahasa dalam penampilannya secara tertulis untuk mengungkapkan suatu gagasan atau pesan. Sementara Semi (2007: 8) mengatakan bahwa menulis itu tidak lain dari upaya memindahkan bahasa lisan ke dalam wujud tulisan dengan menggunakan lambang-lambang grafem. Menulis adalah keterampilan berbahasa yang digunakan untuk berkomunikasi secara tidak langsung, tidak secara tatap muka dengan orang lain.

Nurgiantoro (1995: 273) mengatakan bahwa aktivitas menulis merupakan suatu bentuk manifestasi kemampuan (keterampilan) berbahasa yang paling akhir dikuasai seseorang setelah kemampuan menyimak, berbicara, dan membaca. Jika dibandingkan dengan kemampuan berbahasa lainnya, keterampilan menulis dianggap lebih sulit untuk dikuasai, hal itu bahkan dirasakan oleh penutur asli bahasa yang dimaksud.. Hal demikian bisa terjadi karena kemampuan menulis menuntut penguasaan banya unsur di luar bahasa itu sendiri yang akan dijadikan karangan. Akhadiah dkk. (2006: 1) mengatakan bahwa kegiatan menulis merupakan bagian yang tidak terpisahkan dalam seluruh proses belajar yang dialami mahasiswa selama menuntut ilmu.

Dari beberapa pendapat di atas bisa disimpulkan bahwa menulis bukan hal yang dapat dengan mudah dikuasai. Hal itu disebabkan adanya berbagai hal yang harus dipenuhi sebelum melakukannya. Namun demikian, bukan berarti menulis adalah hal yang mustahil untuk dikuasai oleh seseorang karena pada dasranya kemampuan menulis bukan merupakan sebuah bakat turunan atau bawaan, tetapi hasil yang didapat melalui aktivitas belajar dan berlatih. Menulis memiliki fungsi, manfaat, tujuan, dan jenis-jenis tulisan yang dihasilkan.

Teks editorial merupakan teks yang memerlukan wawasan yang cukup luas tentang suatu topik. Dalam teks editorial juga diperlukan kemampuan untuk berpikir kritis dan berargumentasi.Teks editorial masuk ke dalam jenis teks argumentasi. Editorial berisi tanggapan pihak redaksi sebuah surat kabar terhadap suatu peristiwa atau isu yang aktual.

Kosasih (2019: 205) mengatakan fungsi dari keberadaan editorial bukan sekadar mengetahui adanya peristiwa, tetapi kita pun harus bisa memahami dan bersikap kritis. Hal ini karena dalam teks editorial, ada sikap/ pandangan penulis 
yang bisa memberikan kita pemahaman tentang peristiwa/ keadaan yang diulas dalam tulisannya.

Kosasih (2018:17) juga mengatakan bahwa kekuatan argumen penulis menjadi hal utama dalam teks editorial. Penulis teks editorial sesungguhnya adalah redaksi dari sebuah media massa berdasarkan peristiwa aktual (isu) yang menjadi kepentingan publik. Namun, sebagai bahan pembelajaran, alangkah lebih baik apabila kita pun berlatih menulisnya. Cara tersebut akan bermanfaat pula dalam pengembangan kecakapan tulis menulis secara umum.

Penulisan teks editorial setidaknya memiliki dua tujuan bahwa teks editorial memiliki tujuan mengajak para pembaca surat kabar untuk ikut memikirkan isu yang sedang ramai dibicarakan atau tengah terjadi di sekitar kita dan teks editorial mempunyai tujuan memberikan opini/ pendapat atau pandangan pihak redaksi surat kabar kepada pembaca terkait isu/ peristiwa yang sedang terjadi.

Teks editorial juga memiliki berbagai fungsi di antaranya secara umum memaparkan berita dan akibat dari berita tersebut pada masyarakat, menyampaikan latar belakang dari kaitan suatu berita dengan kenyataan sosial dan faktor yang mempengaruhinya secara menyeluruh, terkadang dibuat analisis tentang kondisi yang fungsinya untuk menyiapkan masyarakat terhadap berbagai kemungkinan yang mungkin terjadi, dan meneruskan penilaian/pandangan moral tentang berita yang diulas.

Agar mampu menulis sebuah teks editorial maka kita perlu mengetahui beberapa ciri teks editorial yaitu, 1) topik tulisan yng diangkat dalam teks editorial selalu aktual (sedang terjadi dan menjadi bahan perbincangan secara luas oleh berbagai lapisan masyarakat), bersifat aktual dan faktual, 2) teks editorial memiliki sifat yang sistematis dan logis, 3) teks editorial merupakan sebuah opini/ pendapat dan pandangan yang bersifat argumentatif, dan 4) teks editorial ditulis dalam kalimat yang singkat, padat, dan jelas.

Terdapat 3 struktur yang menyusun teks editorial/opini, yaitu 1) pernyataan pendapat (tesis), merupakan bagian teks editorial yang berisikan sudut pandang penulis/ redaksi mengenai masalah/isu yang dibahas, biasanya menggunakan sebuah teori yang akan didukung oleh argumen, 2) Argumentasi, bagian ini berisi alasan atau bukti yang dipergunakan untuk memperkuat pernyataan/ pendapat dalam tesis. Argumentasi yang ditulis bisa berbentuk pertanyaan umum/ data sebuah penelitian, pernyataan para ahli, ataupun faktafakta yang berdasarkan sumber/ referensi terpercaya, dan 3) Pernyataan/Penegasan ulang pendapat (reiteration), bagian ini berisi penegasan ulang pendapat dengan didukung oleh fakta di bagian argumentasi guna memperkuat/mempertegas argumen/ pendapat. Penegasan ulang berada di akhir teks.

\section{Persepsi Atas Media Pembelajaran}

Persepsi merupakan bagian penting yang mempengaruhi sikap dan perilaku seseorang. Beberapa ahli telah mengemukakan pendapatnya tentang makna persepsi. Jalaludin Rakhmat (2003: 51) mengatakan bahwa persepsi merupakan pengalaman tentang objek, peristiwa, atau hubungan-hubungan yang diperoleh dengan menyimpulkan informasi dan menafsirkan pesan. Menurut 
Hasibuan (2009:21) persepsi merupakan pengalamam yang dihasilkan melalui panca indera, setiap manusia mempunyai persepsi yang berbeda - beda meskipun mengamati objek yang sama. Menurut Slameto (2010: 102) persepsi merupakan proses yang berkaitan dengan masuknya pesan dan informasi ke dalam otak manusia. Informasi dan pesan tersebut berupa stimulus yang dapat merangsang otak untuk mengolah lebih lanjut dan kemudian mempengaruh seseorang dalam berperilaku. Winardi (2007:46) mengatakan bahwa persepsi seseorang tentang situasi tertentu atau pesan tertentu yang diterima menjadi landasan perilaku seseorang. Media pembelajaran merupakan salah satu komponen dalam kegiatan pembelajaran.

Gerlach dan Ely dalam Arsyad (2006:3) mengatakan bahwa media apabila dipahami secara garis besar adalah manusia, materi, atau kejadian yang membangun kondisi yang membuat siswa mampu memperoleh pengetahuan, keterampilan, atau sikap. Media pembelajaran berarti segala sesuatu yang meliputi alat, lingkungan, strategi, metode yang memungkinkan bagi siswa untuk memperoleh informasi secara konkrit dan bermakna dalam proses pembelajaran serta mempermudah memahaminya untuk mencapai tujuan pembelajaran.Media pembelajaran digunakan untuk memudahkan proses pembelajaran demi tercapainya tujuan pembelajaran. Arsyad (2014: 10) mengemukakan bahwa media pembelajaran adalah segala sesuatu yang dapat digunakan untuk menyampaikan pesan atau informasi dalam proses belajar dan mengajar sehingga dapat merangsang perhatian dan minat siswa dalam belajar. Persepsi yang baik atas media pembelajaran dapat memberikan pengaruh baik pula terhadap kemampuan menulis teks editorial siswa, begitupun sebaliknya.

Dengan demikian dapat disimpulkan bahwa persepsi adalah suatu tanggapan, respons, atau penilaian terhadap sesuatu yang diterima, ditunjukkan dalam wujud berupa perilaku dan tindakan.

Musfiqon (2012: 40) mengatakan bahwa media sebagai alat bantu pembelajaran sering di asumsikan dengan alat peraga. Alat bantu pembelajaran pada awal perkembangannya memang hanya berupa alat bantu visual digunakan dengan tujuan memberikan pengalaman konkret kepada siswa guna menghindarkan mereka dari pengetahuan verbalistik semata. Kemudian pada perkembangan selanjutnya, dan dengan pengaruh teori Edgar Dale tentang kerucut pengalaman dan teori komunikasi, muncullah istilah media pendidikan dalam arti yang lebih luas. Manfaat media pendidikan antara lain 1) merupakan peletakan dasar-dasar berpikir yang konkret dengan mengurangi verbalisme, 2) merupakan upaya memperbesar perhatian siswa, 3) merupakan peletakan pondasi yang sangat penting untuk perkembangan belajar, hal itu membuat pelajaran lebih berkualitas, 4) mengajarkan pengalaman nyata yang dapat mengasah kemauan untuk berusaha sendiri dalam diri siswa, 5) membantu tumbuhnya cara berpikir yang teratur dan berkelanjutan, terutama melalui gambar hidup, 6) membantu menumbuhkan pengertian yang dapat membantu berkembangnya kemampuan berbahasa, 7) mengajarkan pengalaman yang tidak mudah diperoleh dengan cara lain, dan membantu efisiensi dan keragaman yang lebih banyak dalam belajar.

\section{Minat Baca}

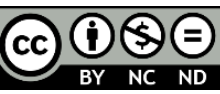


Minat membaca dapat diartikan sebagai dorongan yang timbul atau keinginan yang besar pada diri manusia yang menyebabkan seseorang memberi perhatian pada kegiatan membaca.

Kamah (2002: 5) mengatakan, bahwa minat baca berarti adanya perhatian atau kesukaan (kecenderungan hati) untuk membaca. Farida Rahim (2008: 28) mengatakan bahwa minat baca adalah keinginan yang kuat disertai usaha-usaha seseorang untuk membaca. Seseorang dengan minat baca yang kuat tampak dalam kesediaannya saat mendapat bahan bacaan dan membacanya atas kemauan sendiri.

Dari beberapa pandangan yang dipaparkan di atas dapat ditarik simpulan bahwa minat baca adalah suatu rasa suka dan rasa tertari pada terhadap bahasa tulis (dalam hal ini membaca) yang ditunjukkan dengan keinginan, kesediaan, dan kecenderungan untuk memperhatikan aktivitas tersebut tanpa ada yang menyuruh atau memaksa, dalam hal ini aktivitas tersebut dilakukan dengan kesadarannya, diikuti dengan rasa senang serta adanya usaha-usaha seseorang untuk membaca tersebut dilakukan karena adanya motivasi dari dalam diri.

\section{Hasil}

Berdasarkan hasil pengolahan data diperoleh hasil:

Tabel 1. Hasil Perhitungan Koefisien Korelasi Pengaruh Variabel $X_{1}$ dan $X_{2}$ terhadap Variabel Y

\begin{tabular}{crrrr}
\hline \multicolumn{5}{c}{ Model Summary } \\
\hline Model & R & R Square & Adjusted R Square & $\begin{array}{c}\text { Std. Error of the } \\
\text { Estimate }\end{array}$ \\
\hline 1 & $.948^{\mathrm{a}}$ & .899 & .896 & 2.767 \\
\hline
\end{tabular}

a. Predictors: (Constant), Minat baca, Persepsi atas media pembelajaran

Tabel 2. Rekapitulasi Hasil Perhitungan Pengujian Signifikasi Koefisien Regresi Pengaruh Variabel $\mathrm{X}_{2}$ dengan Variabel $\mathrm{Y}$

\begin{tabular}{crrrrr}
\hline \multicolumn{7}{c}{ ANOVA $^{\text {a }}$} \\
\hline Model & Sum of Squares & Df & Mean Square & \multicolumn{1}{c}{ F } & \multicolumn{1}{c}{ Sig. } \\
\hline Regression & 4919.048 & & 2459.524 & 321.309 & $.000^{\mathrm{b}}$ \\
1 Residual & 551.138 & 72 & 7.655 & & \\
Total & 5470.187 & 74 & & & \\
\hline
\end{tabular}

a. Dependent Variable: Kemampuan Menulis Teks Editorial

b. Predictors: (Constant), Minat Baca, Persepsi Atas Media Pembelajaran 
Tabel 3. Rekapitulasi Hasil Perhitungan Persamaan Garis Regresi Pengaruh Variabel $X_{1}$ dan $X_{2}$ terhadap Variabel $Y$

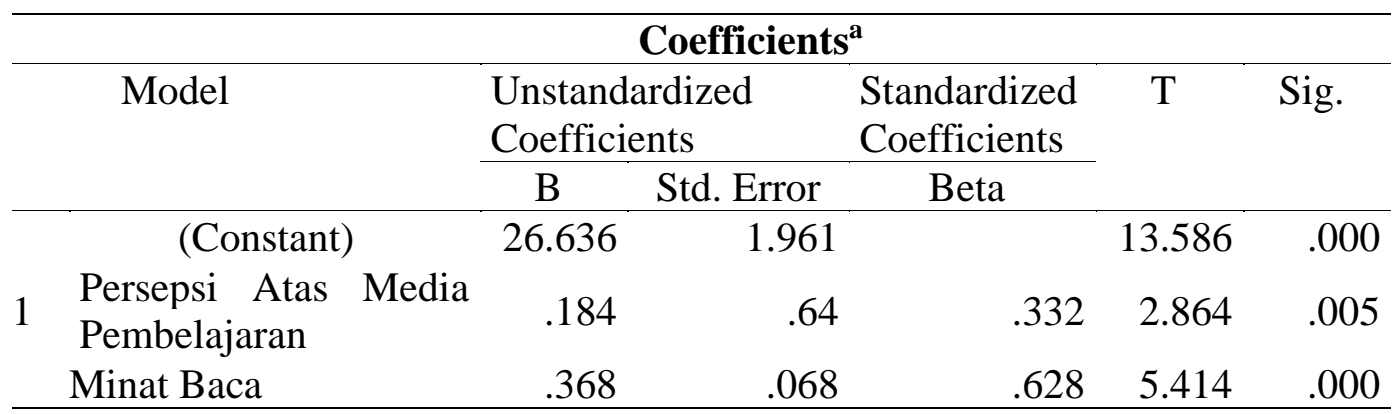

a. Dependent Variable: Kemampuan Menulis Teks Editorial

Sumber: Data diolah

\section{Pembahasan}

Pengaruh Persepsi Atas Media Pembelajaran dan Minat Baca Secara bersama-sama Terhadap Kemampuan Menulis Teks Editorial

Dari tabel 1. di atas terlihat bahwa koefisien determinasi pengaruh variabel bebas Persepsi atas media pembelajaran $\left(\mathrm{X}_{1}\right)$ dan minat baca $\left(\mathrm{X}_{2}\right)$ secara bersamasama terhadap kemampuan menulis teks editorial (Y) adalah sebesar 89,9\%. Berdasarkan nilai tersebut maka dapat dipahami bahwa terdapat pengaruh persepsi atas media pembelajaran dan minat baca terhadap kemampuan menulis teks editorial. Perhitungan pengujian signifikansi koefisien korelasi ganda ini dapat dilihat di Tabel 1. Berdasarkan hasil perhitungan diperoleh bahwa koefisien korelasinya signifikan, sehingga dapat dikatakan bahwa terdapat pengaruh yang signifikan variabel bebas persepsi atas media pembelajaran $\left(\mathrm{X}_{1}\right)$ dan minat baca $\left(\mathrm{X}_{2}\right)$ secara bersama-sama terhadap menulis teks editorial $(\mathrm{Y})$.

Sedangkan koefisien korelasinya sebesar 89,9\% menunjukkan bahwa besarnya kontribusi pengaruh persepsi atas media pembelajaran dan minat baca secara bersama-sama terhadap kemampuan menulis teks editorial $89,9 \%$, sisanya karena pengaruh faktor lain.

\section{Pengaruh Persepsi Atas Media Pembelajaran Terhadap Kemampuan Menulis Teks Editorial}

Hasil penelitian menunjukkan terdapat koraelasi yang signifikan persepsi atas media pembelajaran terhadap kemampuan menulis teks editorial. Hal ini dapat dilihat dari Tabel 3, terlihat bahwa nilai Sig Sig $=0,005<0,05$ dan $\mathrm{t}_{\text {hitung }}=$ 2,864. Karena nilai Sig $<0,005$ dan $\mathbf{t}_{\text {hitung }}>\mathbf{t}_{\text {tabel }}$ maka $\mathrm{H}_{0}$ ditolak yang berarti terdapat pengaruh yang signifikan variabel bebas $\mathrm{X}_{1}$ (persepsi atas media pembelajaran) terhadap variabel terikat $Y$ (kemampuan menulis teks editorial).

Dari hasil pengujian korelasi, pengujian regresi maupun dengan melihat model garis tersebut maka bisa disimpulkan bahwa terdapat pengaruh yang signifikan variabel bebas $\mathrm{X}_{1}$ (persepsi atas media pembelajaran) terhadap variabel terikat Y (kemampuan menulias teks editorial) siswa SMA Negeri di Kabupaten Sukabumi. 


\section{Pengaruh Minat Baca Terhadap kemampuan Menulis Teks Editorial}

Hasil penelitian menunjukkan terdapat korelasi yang signifikan antara minat baca dan kemampuan menulis teks editorial. Hal ini ditunjukkan pada Tabel 3, terlihat bahwa nilai $\mathbf{S i g}=0,000<0,05$ dan $t_{\text {hitung }}=5,414$. Karena nilai Sig $<$ 0,000 dan $\mathbf{t}_{\text {hitung }}>\mathbf{t}_{\text {tabel }}$ maka $\mathrm{H}_{0}$ ditolak yang berarti terdapat pengaruh yang signifikan variabel bebas $\mathrm{X}_{2}$ (minat baca) terhadap variabel terikat $\mathrm{Y}$ (kemampuan menulis teks editorial).

Dari hasil pengujian korelasi, pengujian regresi maupun dengan melihat model garis tersebut maka bisa disimpulkan bahwa terdapat pengaruh yang signifikan variabel bebas $\mathrm{X}_{2}$ (minat baca) terhadap variabel terikat $\mathrm{Y}$ (kemampuan menulis teks editorial) Siswa SMA Negeri di Kabupaten Sukabumi.

\section{SIMPULAN}

Berdasarkan hasil pembahasan, maka simpulan dalam penelitian adalah terdapat pengaruh yang signifikan persepsi atas media pembelajaran dan minat baca secara bersama-sama terhadap kemampuan menulis teks editorial siswa SMA Negeri di Kabupaten Sukabumi. Hal ini dibuktikan dengan perolehan nilai Sig. $=0,000<0,05$ dan $F_{\text {hitung }}=321,309$., terdapat pengaruh yang signifikan persepsi atas media pembelajaran terhadap kemampuan menulis teks editorial siswa SMA Negeri di Kabupaten Sukabumi. Hal ini dibuktikan dengan perolehan nilai Sig. $=0,005<0,05$ dan $t_{\text {hitung }}=2,864$., dan terdapat pengaruh yang signifikan minat baca terhadap kemampuan menulis teks editorial siswa SMA Negeri di Kabupaten Sukabumi. Hal ini dibuktikan dengan perolehan nilai Sig. = $0,000<0,05$ dan $t_{\text {hitung }}=5,414$.

Adapun beberapa saran dapat disampaikan, bahwa dalam pembelajaran, hendaknya guru Bahasa Indonesia perlu memperhatikan tingkat keterampilan menulis siswa. Ini akan membantu mereka dalam konteks penguasaan materi ajar yang diberikan, pihak penyelenggara pendidikan sebaiknya memperhatikan minat baca yang ada pada diri siswa. Pada proses pembelajaran menulis teks editorial, minat baca perlu terus ditingkatkan dengan menerapkan program-program yang ada dan meningkatkan fasilitas membaca agar minat baca siswa terbina dengan baik, dan para guru, khususnya guru Bahasa Indonesia perlu meningkatkan kreativitas dalam menciptakan media pembelajaram sehingga siswa akan lebih tertarik dalam mengikuti pembelajaran Bahasa Indonesia, karena proses pembelajaran akan menjadi lebih interaktif.

\section{DAFTAR PUSTAKA}

Akhadiah, S. (2006). Pembinaan kemampuan menulis bahasa Indonesia. Jakarta: Erlangga.

Arsyad, A. (2006). Media pembelajaran. Jakarta: Rineka Cipta.

Arsyad, A. (2014). Media pembelajaran. Jakarta: PT Raja Grafindo Persada. 
Hasibuan, M. (2009). Organisasi dan motivasi dasar peningkatan produktivitas. Jakarta: PT. Bumi Aksara

Kamah, I. (2005). Pedoman Pembinaan Minat baca. Jakarta. Jakarta: Perpustakaan RI.

Kamus Besar Bahasa Indonesia (Daring). Diakses dari https://kbbi.kemdikbud.go.id/entri/mampu

Kosasih, E. (2018). Cerdas Berbahasa Indonesia untuk SMA/MA Kelas XII kelompok wajib jilid 3 kurikulum 2013. Jakarta: Erlangga.

Kosasih, E. (2019). 22 jenis teks dan strategi pembelajarannya di SMA-MA/SMK. Bandung: Yrama Widya.

Musfiqon, H. M. (2012). Pengembangan media \& sumber pembelajaran. Jakarta: Prestasi Pustaka Publisher.

Nurgiantoro, B. (1995). Penilaian dalam bahasa dan sastra edisi kedua. Yogyakarta: BPFE.

Rahim, F. (2008). Pengajaran membaca di sekolah dasar. Jakarta: Bumi Aksara.

Rakhmat, J. (2003). Psikologi komunikasi. Bandung: PT Remaja Rosdakarya.

Rusyana, Y. (1984). Bahasa dan sastra dalam gamitan pendidikan. Bandung: Diponegoro.

Semi, A. (2007). Dasar-dasar keterampilan menulis. Bandung: Angkasa.

Slameto. (2010). Belajar dan faktor-faktor yang mempengaruhinya. Jakarta: Rineka Cipta.

Winardi. (2007). Motivasi dan pemotivasian dalam manajemen. Jakarta: Raja Grafindo Persada 